\title{
Challenge in Propolis Biocompatibility as a Potential Medicament in Dental Medicine
}

\author{
A Literature Review \\ Fatma Nur Aini ${ }^{1}$ Arya Adiningrat ${ }^{2, *}$ \\ ${ }^{1}$ Bachelor Program, School of Dentistry, Faculty of Medicine and Health Sciences, Universitas Muhammadiyah \\ Yogyakarta, Yogyakarta, Indonesia \\ ${ }^{2}$ Department of Oral Biology and Biomedical Sciences, School of Dentistry, Faculty of Medicine and Health \\ Sciences \\ Universitas Muhammadiyah Yogyakarta, Yogyakarta, Indonesia \\ *Corresponding author. Email: adiningrat@umy.ac.id
}

\begin{abstract}
The application of natural materials in biomedicine has developed quite rapidly. Nowadays, such materials' therapeutic properties become a diminishing topic, including the use of bee products. Bees produce several useful products, one of which is propolis. Propolis or "bee glue" is a honeybee product in the form of a mixed resin from the mixture of certain enzymes in bee saliva and beeswax. Research shows that more than 300 active compounds are found in propolis. The active compounds in propolis are useful as antioxidants, anti-inflammatory, anticancer, antibacterial, antibiofilm, and others. The content and benefits of propolis make it an attractive material to be developed in several dental applications. Some dental literature states that propolis can inhibit oral bacteria activity, a mixture in improving dental materials quality, alternative endodontic regenerative materials, medicament ingredients, post-surgical wound healing, and other uses. By identifying that propolis is a natural ingredient widely used in dentistry, the biocompatibility problem in using propolis must be confirmed before going to the clinical stage. The complex conditions of the oral cavity make the application of propolis have to consider the biocompatibility aspect. Besides that, the regulation for the application of a new material must consider standards guided by the Food and Drug Administration (FDA), the Japanese Ministry of Health and Welfare (JMHW), and the International Organization for Standardization (ISO), requiring producers to carry out adequate testing of their ingredients following biocompatibility evaluation phases as part of the biosafety process and protocols. This study aims to review the biocompatibility of propolis in dentistry. These studies suggested that propolis was sufficiently biocompatible in several dental applications as an alternative medicament at specific concentrations.
\end{abstract}

Keywords: Biocompatibility, Dentistry, Propolis

\section{INTRODUCTION}

Nowadays, many biomedical applications use various types of products from natural ingredients. This condition produces biologically active substances derived from significant natural concern, including propolis as a bee product with therapeutic properties [1]. Propolis is a resinous substance consisting of a mixture of various plant parts and molecules secreted by bees [2]. Bees produce propolis using a combination of beeswax and their saliva [3]. Propolis contains $80 \%$ resin-wax substances, $5 \%$ pollen, and around $15 \%$ essential oils, including other organic compounds $[4,18]$. Variations in composition, smell, colour, and possibly the propolis's therapeutic properties are influenced by the type, season, and food sources available to bees [5]. Based on several current reports, most compounds such as polyphenols, steroids, sugars, terpenoids, amino acids, and others have been reported to be provided by the propolis [6]. Propolis can be used as an antibacterial, anti-inflammatory, aesthetic, anti-tumour, anticancer, antifungal, antimutagenic, and antihepatotoxic agent [7,19].

Studies on propolis use have concluded that propolis is a natural product in great demand to be developed in medicine and dentistry [8]. In dentistry, propolis can be used for surgical wound healing, caries prevention, hypersensitive tooth treatment, aphthous ulcer treatment, avulsed tooth storage media, root canal irrigation solutions, mouthwash, reduction of oral mucositis due to chemotherapy, oral cancer, treatment of gingivitis and periodontitis. It also can inhibit plaque formation, control the oral microbiota, direct pulp capping and analgesic agents, and delay the growth and development of early stages of herpes simplex infection [9,10]. Propolis has a bulk composition, which is an appropriate solvent frequently essential for enhancing the targeted 
compound. One of the commonly used solvents is ethanol from existing solvents such as chloroform, methanol, acetone, etc. [11]. The maceration technique with ethanol is frequently used since this method is considered to have the advantage of a simple, effective, and suitable process for obtaining propolis extract with low wax content and rich in biologically active compounds [12].

The medical application of propolis has increased due to its chemical composition, which has the potential for clinical use in humans [13]. However, the biocompatibility of propolis should be confirmed and resolved before clinical application [14]. The selection and evaluation of a substance for clinical utilization require a serial controlled testing procedure to examine its biosafety and biocompatibility concerning human ethics. Current regulations are guided by the FDA, JMHW, and ISO, requiring manufacturers to conduct appropriate safety concerns via pre-clinical and clinical phases following the regulatory licensing protocol. Considering the oral cavity's complex and heterogeneous environments, biocompatibility (or tissue compatibility) concerns the potential adverse reactions from a particular substance toward the body responses during the application [15]. The suitability of the dental material with living tissue is essential to avoid risks to the patient [16]. The purpose of writing this literature review is to determine the biocompatibility of propolis extract used in several dental applications.

\section{REVIEW}

\subsection{Propolis}

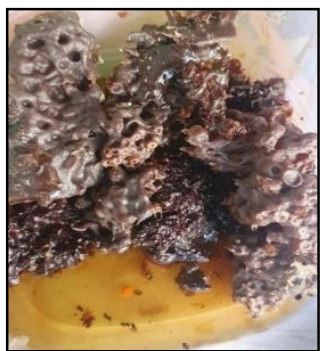

Fig 1. Propolis Apis Trigona from Nglipar, Gunung Kidul, Yogyakarta

The word 'Propolis' comes from the Greek, where pro means "at the entrance to" while polis is close to "community" or "city", which means that it can be functioned for nest protection. Propolis is a mixture of natural resins earned by the bees from several collected ingredients from plants, shoots, and some exudates [17]. It is initially used by the bees to seal holes and cracks, as a sealant and disinfectant, smooth the inner surfaces, maintain the internal hive's temperature, and prevent hive weathering. It is also known as the third most important bee's products since it contains some essential oils, bee pollen, and some other bioactive organic compounds [68].

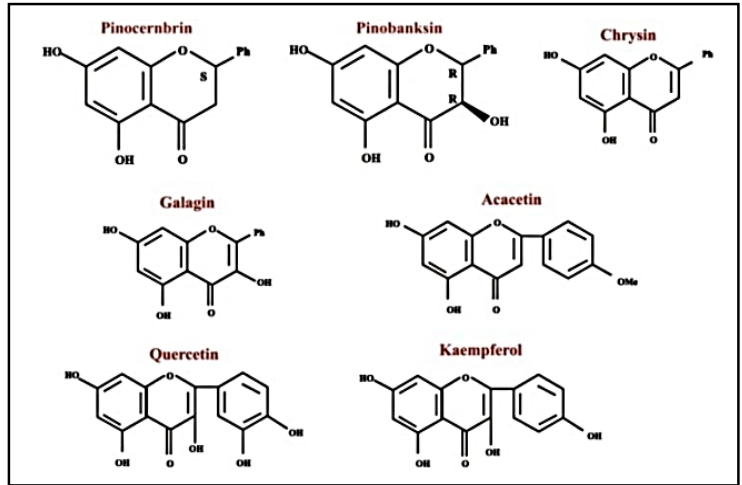

Fig 2. Nomenclature and Chemical Structure of Propolis [52]

Flavonoids, aldehydes, steroids, and a phenolic compound in propolis are the essential macro-structured bioactive organic component's origin. Flavonoid is the most attractive one, previously observed in having several derivatives such as chrysin, luteolin, kaempferol, galanin, quercetin, apigenin, myricetin, resveratrol, pinocembrin, and others by capillary zone electrophoresis analysis of the extracted propolis. In addition to the bioactive organic substances, propolis also harbours several essentials, including thiamine, riboflavin, pyridoxine, ascorbic acid, tocopherol as the vitamins, and some minerals as potassium, magnesium, iron, zinc, copper, calcium, and manganese. Furthermore, it is also reported that propolis may have several enzymes, such as adenosine triphosphate, succinic dehydrogenase, acid phosphatase, and glucose phosphatase $[4,18]$. Propolis has also been studied to have potential antibacterial capacity [7,14,20,21,22], antifungal [23,24,25], antiviral [7,19], antiparasitic [7,19], antioxidant [7,19,27,28,29,30], anti-cancer $[7,19,32]$, anti-inflammatory $[7,19,26]$, antiulcer and antidiabetic effects [7,19].

Table 1. Biological Activity of Propolis Extract

\begin{tabular}{|c|c|c|c|c|}
\hline $\begin{array}{l}\text { Types of } \\
\text { Propolis } \\
\text { Extract } \\
\end{array}$ & $\begin{array}{c}\text { Bees } \\
\text { Species }\end{array}$ & $\begin{array}{c}\text { Origin } \\
\text { of } \\
\text { Propolis } \\
\end{array}$ & $\begin{array}{l}\text { Biological } \\
\text { Action }\end{array}$ & $\begin{array}{l}\text { Refer } \\
\text { ences }\end{array}$ \\
\hline EEP & $\begin{array}{l}\text { Apis } \\
\text { Trigona }\end{array}$ & $\begin{array}{l}\text { Indonesi } \\
\mathrm{a}\end{array}$ & Antibacterial & 14 \\
\hline EEP & $\begin{array}{l}\text { Apis } \\
\text { mellifera }\end{array}$ & Taiwan & Antibacterial & 20 \\
\hline $\begin{array}{l}\text { Dichlorometh } \\
\text { ane Extract } \\
\text { Propolis } \\
\text { (DEP) }\end{array}$ & $\begin{array}{l}\text { Apis } \\
\text { cerana }\end{array}$ & China & Antibacterial & 21 \\
\hline EEP & $\begin{array}{l}\text { Tetragonu } \\
\text { la } \\
\text { laeviceps } \\
\text { Tetrigona } \\
\text { melanoleu } \\
\text { ca }\end{array}$ & Thailand & Antibacterial & 22 \\
\hline EEP & $\begin{array}{l}\text { Unconfir } \\
\text { med }\end{array}$ & Turkey & Antifungal & 23 \\
\hline EEP & $\begin{array}{l}\text { Apis } \\
\text { mellifera }\end{array}$ & Brazil & Antifungal & 24 \\
\hline $\begin{array}{l}\text { Chloroform } \\
\text { Extract } \\
\text { Propolis } \\
\text { (CEP) }\end{array}$ & $\begin{array}{l}\text { Unconfir } \\
\text { med }\end{array}$ & $\begin{array}{l}\text { Norther } \\
\mathrm{n} \\
\text { Jordania } \\
\mathrm{n}\end{array}$ & Antifungal & 25 \\
\hline
\end{tabular}




\begin{tabular}{|l|l|l|l|l|}
\hline EEP & $\begin{array}{l}\text { Unconfir } \\
\text { med }\end{array}$ & $\begin{array}{l}\text { Camero } \\
\text { on }\end{array}$ & $\begin{array}{l}\text { Anti- } \\
\text { inflammatory }\end{array}$ & 26 \\
\hline EEP & $\begin{array}{l}\text { Unconfir } \\
\text { med }\end{array}$ & China & Antioxidant & 27 \\
\hline EEP & $\begin{array}{l}\text { Unconfir } \\
\text { med }\end{array}$ & $\begin{array}{l}\text { Malaysi } \\
\text { a }\end{array}$ & Antioxidant & 28 \\
\hline EEP & $\begin{array}{l}\text { Apis } \\
\text { mellifica } \\
\text { intermissa }\end{array}$ & Algeria & Antioxidant & 29 \\
\hline WEP & $\begin{array}{l}\text { Apis } \\
\text { Mellifera }\end{array}$ & Brazil & Antioxidant & 30 \\
\hline EEP & $\begin{array}{l}\text { Unconfir } \\
\text { med }\end{array}$ & Italia & Antibiofilm & 31 \\
\hline EEP & Trigona & India & Anti-cancer & 32 \\
\hline & & & & \\
\hline
\end{tabular}

\subsection{Propolis Extraction}

Propolis has a complex and bulk structure; thus, it is difficult to apply directly and may require being extracted prior to its utilization. Extraction is the separation of medicinally active components from the source using a selective solvent through an appropriate standard procedure [33]. The extraction procedure is essential in phytochemical analysis. Several conventional methods, such as maceration and percolation extraction methods, are frequently used for screening studies in the bioactive compound analysis. Several advanced extraction methodologies have also been used, including supercritical fluid extraction (SFE), Ultrasound-based extraction, and Microwave-based extraction [34].

Table 2. Various Extraction Methods

\begin{tabular}{|c|c|c|}
\hline Method & Description & References \\
\hline Maceration & $\begin{array}{l}\text { All powdered material is allowed } \\
\text { to contact the solvent in the closed } \\
\text { container for a period of time with } \\
\text { frequent agitation. } \\
\text { This extraction method is } \\
\text { considered simple but has the } \\
\text { disadvantage of long extraction } \\
\text { time and low extraction } \\
\text { efficiency. }\end{array}$ & {$[35,36]$} \\
\hline Percolation & $\begin{array}{l}\text { Perlocators are the tools used for } \\
\text { this technique. The plant material } \\
\text { is moistened with solvent and } \\
\text { allowed to be placed in the } \\
\text { percolation chamber. Then the } \\
\text { plant material is rinsed with } \\
\text { solvent several times until the } \\
\text { active ingredient is extracted. The } \\
\text { solvent is used to the point of } \\
\text { saturation }\end{array}$ & {$[37,64]$} \\
\hline Soxhlet & $\begin{array}{l}\text { This method is widely used when } \\
\text { the desired compound has limited } \\
\text { solubility in a particular solvent. } \\
\text { Finely ground samples are placed } \\
\text { in porous bags or "thimbles" made } \\
\text { of filter paper or cellulose. }\end{array}$ & [34] \\
\hline $\begin{array}{l}\text { Supercritical } \\
\text { fluid } \\
\text { extraction }\end{array}$ & $\begin{array}{l}\text { The extraction method is carried } \\
\text { out with supercritical gases such } \\
\text { as carbon dioxide, nitrogen, } \\
\text { methane, ethane, ethylene, nitrous } \\
\text { oxide, sulfur dioxide, propane, } \\
\text { propylene, ammonia, and sulfur } \\
\text { hexafluoride to extract the active } \\
\text { ingredients. The plant material is } \\
\text { stored in vessels filled with gas } \\
\text { under controlled conditions such } \\
\text { as temperature and pressure. }\end{array}$ & {$[38]$} \\
\hline
\end{tabular}

\begin{tabular}{|c|c|c|}
\hline $\begin{array}{l}\text { Microwave- } \\
\text { assisted } \\
\text { extraction }\end{array}$ & $\begin{array}{l}\text { In this method, microwave energy } \\
\text { facilitates the separation of the } \\
\text { active ingredient from the plant } \\
\text { material into the solvent. } \\
\text { In contrast to the classical method, } \\
\text { microwave-assisted extraction } \\
\text { heats the entire sample } \\
\text { simultaneously. } \\
\text { extraction, heat interferes with } \\
\text { weak hydrogen bonds as the } \\
\text { rotation of molecular dipoles and } \\
\text { dissolved ions' migration } \\
\text { increases the solvent's penetration } \\
\text { into the sample or matrix. }\end{array}$ & {$[65]$} \\
\hline $\begin{array}{l}\text { Ultrasound- } \\
\text { assisted } \\
\text { extraction }\end{array}$ & $\begin{array}{l}\text { This technique is an advanced } \\
\text { technique that has the ability to } \\
\text { extract a large number of bioactive } \\
\text { compounds in it with a shorter } \\
\text { extraction time, which could be } \\
\text { the main advantage of this } \\
\text { technique }\end{array}$ & [66] \\
\hline
\end{tabular}

One of the most important factors affecting the efficiency of extraction of bioactive compounds from natural materials and their health benefits is solvent extraction [39]. Some of the frequently used extracting solvents are water, ethanol, methanol, and dichloromethane [40].

\subsubsection{Extract Ethanol Propolis (EEP)}

Ethanol is the most widely used solvent as it can produce propolis extract with low wax content and rich in biologically active compounds [41]. Ethanol is an efficient solvent for extracting natural substances, especially when it is used at $60 \%(\mathrm{v} / \mathrm{v})$ and in a ratio of $35 \mathrm{ml} / \mathrm{g}$ dry matter, for 30 minutes at $60-65^{\circ} \mathrm{C}$ [42]. A mixture of ethanol and water with the proportion of 60:40 $(\mathrm{v} / \mathrm{v})$ is most suitable for obtaining extracts with high phenolic compounds and antioxidant activity; therefore, ethanol is a material that is quite in demand as a solvent [43].

\subsubsection{Water Extract Propolis (WEP)}

Research by Rocha et al. [30] conducted a study by chemically characterizing WEP and EEP and evaluating in vitro antioxidant/antimicrobial activity extracts and the safety of WEP through the determination of its genotoxic potential. The results of this study indicated that both extracts exhibited antioxidant and antimicrobial activity. WEP proved to be quite safe, marked by the XTT colorimetric assay WEP with a $25 \%$ concentration or lower and the percentage of cell viability V79> $80 \%$.

\subsubsection{Methanol Extract Propolis (MEP)}

Lawal et al. [44] conducted a study revealing that 200 grams of Nigerian propolis were extracted in $1600 \mathrm{~mL}$ of absolute methanol. Their research showed the existence of various important phytochemicals in the methanol extract of Nigerian bee propolis, such as alkaloids, 
flavonoids, saponins, anthraquinone, tannins, glycosides, phlobatnins. The presence of many chemical components is an indication that the methanol extract of Nigerian bee propolis, when properly filtered, has great potential as a medicament material.

\subsubsection{Dichloromethane Extract Propolis (DEP)}

The research conducted by Yan et al. [21] with the propolis method was carried out by stirring in the dichloromethane solvent. The result was that the propolis extract with dichloromethane had the highest methylene content and the maximum type of propolis component was effective compared to the $90 \%$ ethanol extraction method, $70 \%$ ethanol, and ethanol-ligarin extraction method. Research related to DEP biocompatibility conducted by Utispan et al. [45] showed that cytotoxic activity in HN30 cells with viability decreased significantly with $200 \mu \mathrm{g} / \mathrm{ml}$ DEP, HN30 cell viability $<75 \%$, and $\mathrm{HN} 31$ cell viability $<50 \%$.

\subsection{Applications of Propolis in Dentistry}

Along with the increasing interest in using natural ingredients as medicament alternatives, propolis's therapeutics are widely used in dentistry. Propolis in dental materials is used in the modification of GICs as EEP is proven to be able to provide good antibacterial properties in the modification [46]. Besides, EEP incorporated in ceramic-reinforced glass ionomer (Amalgomer CR) can improve its mechanical properties [47].

Propolis in orthodontics effectively reduces the marginal bleeding index in patients during orthodontic treatment [48]. Mouthwash containing propolis can reduce plaque accumulation in patients with fixed orthodontic treatment [49]. Propolis in endodontics showed that propolis could be compared with Triple Antibiotic Paste (TAP) as a disinfection treatment option for regenerative endodontics. Furthermore, propolis paste was able to induce a progressive increase in root length and dentin thickness, as well as a decrease in apical diameter similar to MTA [5]. Another use of propolis in endodontics is that propolis can be used as an alternative for proper root canal irrigation. Propolis also can reduce the development of Enterococcus faecalis and Candida albicans [11]. The addition of EEP to the calcium hydroxide paste increases its antibacterial activity. It has been shown that the flavonoid content of propolis provides slightly better antimicrobial activity than calcium hydroxide without propolis [9].

Propolis in oral medicine in patients with recurrent aphthous ulcers provides a personal report that propolis reduces recurrent aphthous ulcers [50]. In oral surgery, studies showed that mouthwash with propolis could improve wound healing characterized by epithelial repair [51]. Propolis in periodontics can be used in subgingival irrigation. This propolis extract during periodontal treatment gives better results than root planning and scaling. Besides, propolis extract, when it is used in gingival pockets, is beneficial for healing periodontal disease [52]. Propolis in pedodontics is used as the age group of children is a group that is susceptible to a drug. Complications/side effects due to the use of artificial drugs have paved the way for natural products such as propolis for pharmacotherapy purposes. The potential of propolis for dental treatment in children is as a mouthwash, anti-cariogenic, direct pulp, pulpotomy, endodontic therapy, avulsion tooth storage media, new bone formation in children, and wound healing. Propolis can be used as an alternative to pedodontics medicaments that are easy to use, patient-friendly, and easy to reach in the future [53].

\subsection{Propolis Biocompatibility}

In dentistry, propolis' therapeutic properties as natural ingredients are mostly carried out in the form of test ingredients or extracts. Biocompatibility challenges various types of biological models with test materials or extracts. Researchers must follow FDA guidelines and ISO 10993 standards. Biocompatibility analysis or biological testing methods should be carried out in stages from initial screening of new substances to product release, adhering to periodic clinical, nonclinical, preclinical, and post clinical audit testing to meet FDA and international standards [54].

TABLE I. ISO STANDARDS FOR BIOCOMPATIBILITY TESTING

\begin{tabular}{|l|l|}
\hline \multicolumn{1}{|c|}{ ISO Standard } & \multicolumn{1}{|c|}{ Title } \\
\hline ISO 10993 & Biocompatibility \\
\hline ISO 10993-1:2018 & $\begin{array}{l}\text { Evaluation and testing in the risk } \\
\text { management process }\end{array}$ \\
\hline ISO 10993-3:2014 & $\begin{array}{l}\text { Genotoxicity, carcinogenicity, and } \\
\text { reproductive toxicity tests }\end{array}$ \\
\hline ISO 10993-4:2016 & Selection of tests for interaction with blood \\
\hline ISO 10993-5:2015 & In vitro cytotoxicity test \\
\hline ISO 10993-10:2017 & Skin irritation and sensitization testing \\
\hline ISO 10993-11:2016 & Systemic toxicity test \\
\hline ISO 10993-12:2017 & $\begin{array}{l}\text { Preparation of samples and reference } \\
\text { materials }\end{array}$ \\
\hline ISO 15223-1:2015 & $\begin{array}{l}\text { Symbols used on labels, markings, and } \\
\text { medical device information }\end{array}$ \\
\hline
\end{tabular}

Biocompatibility is the ability of a material to obtain an appropriate biological response after application. When a material is placed into living tissue, it interacts with complex biological systems and produces a biological response [55]. Biocompatibility is considered biologically compatible with no toxic, adverse, or immunological response in living tissue. When an object is introduced into the body without an immune response, it can be considered biocompatible. The biocompatibility test was carried out in stages starting from in vitro, in vivo to entering clinical trials [56]. 


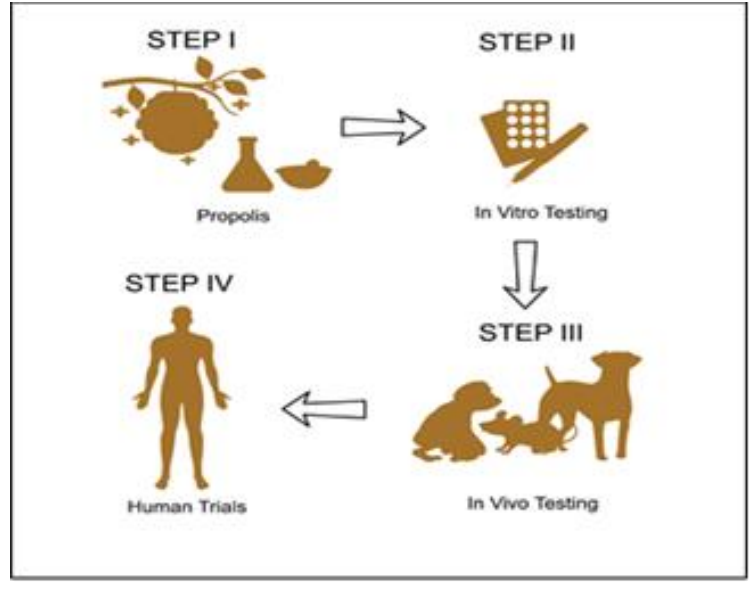

Fig 3. Summary of the systematic approach to the biological evaluation of medical devices as part of a risk management process [67].

\subsubsection{In Vitro Propolis Biocompatibility}

a) Biocompatibility of Extract Ethanol Propolis was investigated by Fauzi et al. [14]. Propolis Apis trigona from Nglipar, Yogyakarta, was selected in this study. In this study, adult human fibroblast cells as an in vitro model were closely related to cell populations in dental pulp, root canals, lamina propria gingiva, and oral mucosa with open wounds. MTT test with ELISA reader at a wavelength of $550 \mathrm{~nm}$ was carried out for cytotoxic analysis, and the results showed that the lower the EEP concentration was, the higher the cell viability would be. EEP Apis Trigona is a compound with a concentration of $0.0025 \%$ viability> $75 \%$.

b) Research conducted by Al-Shaher, et al. [57] tested the tolerance of fibroblasts from the periodontal ligament (PDL) and dental pulp to propolis in vitro. Cells from human dental pulp and PDL were obtained from healthy third molars and then treated with various propolis' concentration from 0 to $20 \mathrm{mg} / \mathrm{ml}$. Cell viability after propolis treatment was analysed by crystal violet staining of cells followed by spectrophotometric analysis. Outcome data revealed that concentrations of $4 \mathrm{mg} / \mathrm{ml}$ or lower resulted in $>75 \%$ viability of PDL cells or pulp fibroblasts.

c) The study of Shi et al. [58] evaluated the effect of mineral trioxide aggregate (MTA) and Brazilian propolis on the viability of human dental pulp cells (hDPC). EEP as a test material was diluted with culture media (DMEM) to $10,20,40,80$, and $160 \mu \mathrm{g} / \mathrm{mL}$; MTA was also diluted with 1: 1, 1: 2, 1: 4, and 1: 8 . Cell viability was evaluated with the CCK-8 Kit (CCK-8; Dojindo, Kumamoto, Japan) on days 1, 5, 7, and 9. Absorbance was conducted with a wavelength of $450 \mathrm{~nm}$. The viability of hDPC was slightly higher at the $10 \mu \mathrm{g} / \mathrm{mL}$ EEP dilution than the other dilutions. The results of this study indicated that EEP and MTA significantly increased the viability of hDPC compared to the control group at days 7 and 9. This in vitro study showed that Brazilian propolis showed similar cell viability to MTA.

d) Grenho et al. [59] conducted a study on the biocompatibility of nanohydroxyapatite containing propolis. The propolis' red and green ethanol extracts were diluted in a hydroalcoholic solution $(50 \%(\mathrm{v} / \mathrm{v}))$ to make 6,12 , and $25 \mu \mathrm{g} \mathrm{ml-1}$ solutions. Furthermore, the ceramic samples were immersed overnight, at room temperature, in this solution. NanoHA samples were also immersed in hydroalcoholic solution without propolis and used as control and referred to nanoHA without treatment. The results of this study showed that nanohydroxyapatite containing propolis was quite compatible.

\subsubsection{In Vivo Propolis Biocompatibility}

a) Raheem et al. [60] conducted a study on Egyptian propolis nanoparticles' in vivo biocompatibility as root canal nano sealers. The EEP nano sealer can be used as an innovative root canal sealant, with improved sealing capabilities, and in vivo biocompatibility. This research revealed that propolis nanoparticle sealer could be applied as a substitute for the current sealer, which had a toxic effect.

b) Research by Almeida et al. [61] analysed the toxicity of propolis ethanol extract using Artemia franciscana (A. franciscana) as a model. In the plates, ten Artemia franciscana nauplii were given $20 \mathrm{~mL}$ of ethanol extract of propolis at a concentration of $8 \%$ and incubated for 24 hours at room temperature in the dark. This procedure was carried out in a triplicate manner. The mortality rate was defined as $\%$ mortality $=$ (number of individuals who died $\times 100$ ) / total number of individuals, and the degree of toxicity was classified according to observed mortality: 0-9\% = non-toxic (NT); 10-49= slightly toxic $(\mathrm{ST}) ; 50-89 \%=$ toxic $(\mathrm{T}) ; 90-100 \%=$ highly toxic (HT).The toxicity test result showed that the extract tested concentration was classified as HT (100\%) based on the A. franciscana mortality rate, or it could be concluded that the concentration tested was very toxic.

c) The research by Eskandarinia et al. [62] evaluated the biocompatibility of Bilayer Wound Dressings from polycaprolactone/gelatine (PCL/Gel), polyurethane and ethanol extracts of propolis (PU/EEP) and polyurethane and ethanol extracts of propolispolycaprolactone/gelatine (PU / EEP-PCL/Gel) with fibroblast (normal) cells from the L929 mouse. A total of 104 L929 cells were inserted in each well, and $400 \mu \mathrm{L}$ of RPMI culture medium was supplemented with $10 \%$ fetal bovine serum (Sigma, USA). Furthermore, 1\% penicillin/streptomycin (Sigma, USA) was added to each well. There were 3 control wells. 24-well cell culture plates were incubated at $37 \mathrm{C}$ in a $5 \% \mathrm{CO} 2$ atmosphere, and the culture media refreshed every 48 hours. Cell viability was evaluated on days 1,4 , and 7 of culture 
using the MTT assay following the kit manufacturer's protocols (Sigma-Aldrich, USA). Optical density was recorded at $590 \mathrm{~nm}$ by a microplate reader (Bio-RAD 680 , USA). PBS solution was used to remove nonadherent cells through several washes. Furthermore, incubation with 2 vol\% glutaraldehyde solution for 1 hour was used to fix the sample. After several PBS was washed, the samples were still dehydrated in ethanol concentration $(30,50,70,80,90,95,100 \%)$ and dried. In our previous study, $0.5 \mathrm{wt} \%$ EEP showed the most suitable biocompatibility for cells. L929 fibroblasts were compared to $0.25 \mathrm{wt} \%$ and $1 \mathrm{wt} \%$ concentrations. Therefore, an EEP concentration of $0.5 \mathrm{wt} \%$ was used in this study. The results of this study indicated that PU/EEP and PU/EEP-PCL/Gel with these concentrations were quite biocompatible. The viability was investigated after incubation of 1, 4, and 7 days with samples. After 7 days of incubation with PU / EEP, cell viability was $140 \%$, and PU/EEP-PCL/Gel showed a cell viability of $175 \%$. PCL / Gel and PCL/Gel-PUEEP samples showed more proproliferative effects on fibroblast cells compared to PU / EEP, which became significant from the 4th day of incubation.

d) Mori et al. [16] conducted a study to evaluate calcium hydroxide and propolis's biocompatibility in rat subcutaneous tissue. The study was conducted on 15 male Wistar rats by creating an incision in the back of each test animal to insert 4 tubes: one empty tube; one containing zinc oxide-eugenol cement, and the other two tubes were filled with an experimental paste prepared with $1 \mathrm{~g} \mathrm{CH}$ (Biodinamica) powder and $2 \mathrm{~mL}$ of $11 \%$ nonalcoholic propolis. After 7, 14, and 30 days, the test animals were euthanized, and the specimens were prepared for histochemical technics with haematoxylin, and eosin staining was analysed by light microscopy. The analysis was carried out by taking into account the presence and type of inflammatory processes, proliferation of connective tissue, or the occurrence of destructive processes, such as abscesses or tissue necrosis. The inflammatory process was present in several parts, with a large number of neutrophils. However, on the 14th and 30th day, the inflammatory process occurred to be mild or insignificant, characterized by several parts showing lymphocytes and macrophages, which characterized moderate inflammation. The experimental paste (test paste) was assessed as biocompatible with tissues after 14 days. By taking into account the results of this study, it was concluded that 1 gram of calcium hydroxide with $2 \mathrm{~mL}$ of $11 \%$ non-alcoholic propolis as the material was tested for biocompatibility with connective tissue.

e) Meneses et al. [46] conducted research related to the modification of GICs with ethanol propolis extract (EEP), where GIC was as cement while EEP was $10 \%$, $25 \%$, and $50 \%$ as a liquid. These modifications' biocompatibility was evaluated by analysing Wistar rat tissue under an optical microscope by observing cellular changes at different time intervals. The results of this study indicated the intensity of the histological changes. During the study, tissue biocompatibility was investigated by qualitative-quantitative analysis based on the intensity of tissue aggression caused by the treatment. In this study, initial intense inflammation was observed when 10 and 25\% EEP were added at 7 and 15-day intervals. The histocompatibility analysis results showed that the intensity of histological changes in the test material proved to be inversely related to the concentration of propolis addition. In other words, the lower the concentration of the test material was, the more compatible the material would be. Semen Ketac test material with $50 \%$ EEP was the one that showed the smallest inflammatory process. The results in this study indicated the compatibility of the test material within the parameters considered safe, which was attributed to the fact that EEP was not used in its liquid form or paste form but as an intrinsic part of the polymerized GIC and was slowly released into living tissue.

\subsubsection{Propolis Biocompatibility in Clinical Studies}

a) Research by Kripal et al. [63] assessed the effectiveness of propolis $5 \%$ mouthwash in chronic generalized gingivitis and compared the effectiveness of $5 \%$ propolis mouthwash to chlorhexidine mouthwash. This study was conducted on a sample of 45 patients randomly selected in the 18-70 years age group, divided into 3 groups: Group I with 15 patients treated with $5 \%$ propolis mouthwash, group II with 15 patients treated with the control group chlorhexidine gargle, and group III with 15 patients treated with normal saline (placebo). After scaling and root planning, subjects were advised to rinse their mouth with the instructions to rinse their mouths in the morning after brushing their teeth and after breakfast, and evening after dinner and before going to bed consistently for 5 days. This study showed a decrease in the gingival index (GI) and plaque index (PI) in group 1 treated after scaling and root planning with propolis when it was compared to the other 2 groups treated after scaling and root planning. The composition of 5\% propolis mouthwash as a mouthwash after scaling and root planning in the treatment of chronic generalized gingivitis showed positive results. This study's data indicated that propolis mouthwash was more effective than other mouthwashes in accumulating plaque and gingival inflammation. The study showed that propolis could be used as an alternative to mouthwash. However, in this study, the propolis ingredients and extraction method were not included.

b) Research by Dehghani et al. [49] evaluated the effect of propolis and chlorhexidine mouthwash on plaque and gingival index in patients undergoing orthodontic treatment. $30 \mathrm{~g}$ Propolis material was mixed with $100 \mathrm{ml}$ distilled water, then mixed with a mixer at 
$30^{\circ} \mathrm{C}$ for 2 hours. After the resulting mixture, the propolis extract was centrifuged from purified water at $30 \%$ as the base concentration. The propolis mixing solution was $1 \%$ with a saline concentration of $0.25 \%$, and together with the essential oil of turmeric and flavour, a mouthwash solution was produced. The prepared solution was poured into 60 equal bottles. In this triple-blind study in total, 37 patients aged 15 to 35 years who had undergone fixed orthodontic treatment were studied. After that, one mouth rinse containing either Propolis or Chlorhexidine was randomly prescribed to the patient. Patients were asked to use mouthwash twice a day after brushing their teeth for three consecutive weeks. Plaque, gingival, and periodontal status indicators (PI, GI, CPI) were determined at the beginning and the end of the treatment (after three weeks) for each patient. This study indicated that the PI GI and CPI of patients with propolis mouthwash were higher than patients with chlorhexidine mouthwash. However, propolis mouthwash was considered more compatible. This condition is in line with the statement of Kubiliene et al. [12] that aquades was less effective in producing extracts with high bioactive compounds.

Table 3. Results of the propolis biocompatibility

\begin{tabular}{|c|c|c|c|c|c|}
\hline Test & $\begin{array}{l}\text { Types of } \\
\text { Propolis }\end{array}$ & Concentration & Sample & Results & $\begin{array}{l}\text { Referenc } \\
\text { es }\end{array}$ \\
\hline \multirow{4}{*}{ In Vitro } & EEP & $\begin{array}{l}0 ; \quad 0,0003125 ; 0,000625 \\
0,00125 ; 0,0025 ; 0,005 ; 0,01 ; \\
0,05 \% ; 0,1 \%\end{array}$ & Fibroblast cells & $\begin{array}{l}\text { in concentration of } 0.0025 \% \text { produces a } \\
\text { viability> } 75 \%\end{array}$ & {$[14]$} \\
\hline & EEP & $0-20 \mathrm{mg} / \mathrm{ml}$ & PDL fibroblasts & $\begin{array}{l}\leq 4 \mathrm{mg} / \mathrm{ml} \text { results in viability of PDL cells or } \\
\text { pulp fibroblasts }>75 \%\end{array}$ & {$[57]$} \\
\hline & EEP & $10,20,40,80$, dan $160 \mu \mathrm{g} / \mathrm{mL}$ & $\mathrm{hDPC}$ & $10 \mu \mathrm{g} / \mathrm{mL}$ yields viability $>60 \%$ & {$[58]$} \\
\hline & EEP & $\begin{array}{l}\text { nanoHA impregnated with } \\
12 \mu \mathrm{gml}-1 \text { of red (nanoHA RP) } \\
\text { and green propolis (nanoHA- } \\
\text { GP) }\end{array}$ & $\begin{array}{l}\text { 3T3-L1 mouse } \\
\text { fibroblast }\end{array}$ & $\begin{array}{l}\text { On day } 7 \text { nanoHA-EP } 12 \mu \text { gml- } 1 \text { showed higher } \\
\text { viability }(125 \%) \text { than nanoHA-GP }(110 \%)\end{array}$ & [59] \\
\hline \multirow{5}{*}{ In Vivo } & EEP & $\begin{array}{l}\text { EEP } 0.5 \% \text { sealer (group I) and } \\
\text { nano sealer (group II) }\end{array}$ & $\begin{array}{l}20 \text { adult male Wistar } \\
\text { albino rats }\end{array}$ & $\begin{array}{l}\text { - The sealer group shows a higher absorbance } \\
\text { value than the noanosealer. } \\
\text { Group II (nano sealer), there is a dense fibrous } \\
\text { band of tissue rich in fibroblasts and collagen } \\
\text { fibers that appear thicker and more regular than } \\
\text { group I. Ep Nanosealer promotes higher healing } \\
\text { rates than PE sealer }\end{array}$ & [60] \\
\hline & EEP & EEP 8\% & $\begin{array}{l}\text { Artemia franciscana } \\
\text { (A. franciscana) }\end{array}$ & $\begin{array}{l}\text { After incubation of } 24 \text { hours, the extract } \\
\text { concentrations tested were classified as highly } \\
\text { toxic HT }(100 \%) \text { based on the A. franciscana } \\
\text { mortality rate }\end{array}$ & {$[61]$} \\
\hline & EEP & $\begin{array}{l}\text { EEP WT\% } \\
\text { ethanol extract of propolis (PU / } \\
\text { EEP) and polyurethane and } \\
\text { ethanol extract of propolis- } \\
\text { polycaprolactone / gelatin (PU / } \\
\text { EEP-PCL / Gel) }\end{array}$ & $\begin{array}{l}\text { the subcutaneous } \\
\text { connective tissue of } \\
\text { mouse }\end{array}$ & $\begin{array}{l}\text { EEP } 0.5 \text { wt } \% \\
\text { ethanol extract of propolis (PU / EEP) and } \\
\text { polyurethane and ethanol extract of propolis- } \\
\text { polycaprolactone / gelatin (PU / EEP-PCL / } \\
\text { Gel) }\end{array}$ & {$[62]$} \\
\hline & WEP & $\begin{array}{l}1 \mathrm{~g} \mathrm{CH} \text { (Biodinâmica) powder } \\
\text { and } 2 \mathrm{~mL} \text { of } 11 \% \text { non-alcoholic } \\
\text { propolis }\end{array}$ & 15 male Wistar rats & $\begin{array}{l}1 \text { gram of calcium hydroxide with } 2 \mathrm{~mL} \text { of } 11 \% \\
\text { non-alcoholic propolis as material tested for } \\
\text { biocompatibility with connective tissue }\end{array}$ & {$[16]$} \\
\hline & EEP & $\begin{array}{l}\text { EEP } 10 \%, 25 \%, \text { dan } 50 \% \\
\text { sebagai liqiud }\end{array}$ & Wistar mouse & $\begin{array}{l}\text { Ketac cement with } 50 \% \text { EEP is the one that } \\
\text { shows the least inflammatory process. }\end{array}$ & [46] \\
\hline \multirow{2}{*}{ Clinic } & $\begin{array}{l}\text { unconfir } \\
\text { med }\end{array}$ & $5 \%$ propolis mouthwash & $\begin{array}{l}45 \text { patients in the } 18- \\
70 \text { year age group } \\
\text { had scaling and root } \\
\text { planning }\end{array}$ & $\begin{array}{l}\text { Indicators of plaque status, gingiva in the } \\
\text { mouthwash group 5\% propolis mouthwash } \\
\text { lower patients with chlorhexidine mouthwash }\end{array}$ & {$[63]$} \\
\hline & WEP & $1 \%$ propolis mouthwash & $\begin{array}{l}37 \text { patients aged } 15 \\
\text { to } 35 \text { who underwent } \\
\text { fixed orthodontic } \\
\text { treatment }\end{array}$ & $\begin{array}{l}\text { Indicators of plaque, gingival, and periodontal } \\
\text { status (PI, GI, CPI) in the sample group with } 1 \% \\
\text { propolis mouthwash were higher than patients } \\
\text { with chlorhexidine mouthwash. }\end{array}$ & [49] \\
\hline
\end{tabular}




\section{CONCLUSION}

Based on the existing reports, propolis as a natural compound was considered to be used in dentistry. Most of the propolis extract was produced by extraction method using ethanol as it was considered adequate to be able to produce extracts with high bioactive compounds. Besides, ethanol extract seemed to be more biocompatible than extracts with other solvents. Ethanol extract of propolis was the material most frequently used in dental applications. Propolis ethanol extract could be used effectively and compatible with the host by using the right concentration based on the study reports' reference. Evaluation of propolis' biocompatibility in dentistry was generally carried out in vitro and in vivo. However, reports on clinical biocompatibility studies are still very limited.

\section{ACKNOWLEDGMENTS}

We would like to thank the ICOSI UMY committee for giving critical suggestions and reviews for this article prior to publication.

\section{REFERENCES}

[1] M. Kieliszek, K. Piwowarek, A. M. Kot, S. Błażejak, A. Chlebowska-Śmigiel, and, I. Wolska, "Pollen and bee bread as new health-oriented products: A review," Food Science \& Technology, Vol. 71, pp. 170-180, 2018.

[2] L. M. Santos, M. S. Fonseca, A. R. Sokolonski, K. R. Deegan, R. P. C. Araújo, M. A. Umsza-Guez, et al., "Propolis: Types, Composition, Biological Activities, and Veterinary Product Patent Prospecting," Journal Sciences Food Agric., Vol. 100(4), pp. 1369-1382, 2019.

[3] A. Braakhuis, "Evidence on the Health Benefits of Supplemental Propolis," Nutrients, Vol. 8;11(11), pp. $2705,2019$.

[4] R. Silva-Carvalho, F. Baltazar, and C. Almeida-Aguiar, "Propolis: A Complex Natural Product with a Plethora of Biological Activities That Can Be Explored for Drug Development," Hindawi Publishing Corporation Evidence-Based Complementary and Alternative Medicine, Vol. 2015:206439, 2015.

[5] M. M. El-Tayeb, A. M. Abu-Seida, S. H. El Ashry, and S. A. El-Hady, "Evaluation of Antibacterial Activity of Propolis on Regenerative Potential of Necrotic Immature Permanent Teeth in Dogs," BMC Oral Health., Vol. 19(1):174, 2019.

[6] J. Kocot, M. Kiełczykowska, D. Luchowska-Kocot, J. Kurzepa, and I. Musik, "Antioxidant Potential of Propolis, Bee Pollen, and Royal Jelly: Possible Medical Application," Hindawi Oxidative Medicine and Cellular Longevity. Vol. 2018:7074209, 2018.

[7] S. I. Anjum, A. Ullaha, K. A. Khan, M. Attaullah, H. Khan, H.Ali, et al., "Composition and Functional Properties of Propolis (Bee Glue) : A Review," Saudi
Journal of Biological Sciences, Vol.26(7), pp. 16951703, 2018.

[8] C. Virga, A. Aguzzi, and V. Lopez, "Propolis: A Therapeutic Alternative for Oral Cavity," Journal of Dental Science, Oral and Maxillofacial Research, Vol. 1(2), pp. 67-70, 2018.

[9] A. J. Abbasi, F. Mohammadi, M. Bayat, S. M. Gema, H. Ghadirian, H. Seifi, et al., "Applications of Propolis in Dentistry: A Review," Ethiopian Journal of Health Sciences, Vol. 28(4), pp. 505-512, 2018.

[10] V. L. S. Kumar, "Propolis in Dentistry and Oral Cancer Management," North American Journal of Medical Sciences, Vol. 6(6), pp. 250-259, 2014.

[11] Z. Ahangari, M. Naseri, and F. Vatandoost, "Propolis: Chemical Composition and Its Applications in Endodontics," Iranian Endodontic Journal, Vol. 2018;13(3), pp. 285-292, 2018.

[12] L. Kubiliene, V. Laugaliene, A. Pavilonis, A. Maruska, D. Majiene, K. Barcauskaite, et al., "Alternative Preparation of Propolis Extracts: Comparison of Their Composition and Biological Activities," BMC Complementary Medicine and Therapies, Vol. 156(2015), 2015.

[13] V. Mujica, R. Orrego, J. Pérez, P. Romero, P. Ovalle, J. Zúñiga-Hernández, et al., "The Role of Propolis in Oxidative Stress and Lipid Metabolism: A Randomized Controlled Trial," Hindawi EvidenceBased Complementary and Alternative Medicine, Vol. 2017:4272940, 2017

[14] A. F. Fauzi, S. K. Indiana, R. H. Wicaksono, and A. Adiningrat, "A Challenge in Ethanolic Propolis Utilization from Apis Trigona as an Oral Antimicrobial Agent," Journal of International Dental and Medical Research, Vol. 11(2), pp. 682-686, 2018.

[15] B. Swetha, S. Mathew, B. V. S. Murthy, N. Shruthi, and S. H. Bhandi, "Determination of Biocompatibility: A review," International Dental \& Medical Journal of Advanced Research, Vol. 1, pp. 1-6, 2015.

[16] G. G. Mori, S. D. S. Rodrigues, S. T. Shibayama, M. Pomini, and C. O. F. D. Amaral, "Biocompatibility of a Calcium Hydroxide-ropolis Experimental Paste in Rat Subcutaneous Tissue," Brazilian Dental Journal, Vol.25(2), pp. 104-108, 2014.

[17] V. D. Wagh, "Propolis: A Wonder Bees Product and Its Pharmacological Potentials," Hindawi Publishing Corporation Advances in Pharmacological Sciences, Vol. 2013;308249, 2013.

[18] V. R. Pasupuleti, L. Sammugam, N. Ramesh, and S. H. Gan, "Honey, Propolis, and Royal Jelly: A Comprehensive Review of Their Biological Actions and Health Benefits," Hindawi Oxidative Medicine and Cellular Longevity, Vol. 2017:1259510, 2017.

[19] K. Pobiega, K. Krasniewska, D. Derewiaka, and M. Gniewosz, "Comparison of The Antimicrobial 
Activity of Propolis Extracts Obtained by Means of Various Extraction Methods," Springer Journal Food Sciences Technolgy, Vol. 56(12), pp. 5386-5395, 2019.

[20] C. Chen, Y. Chien, Y. Yu, and Y. Chen, "Extraction and Analysis of Taiwanese Green Propolis," Journal of Visualized Experiments," Vol. 7;(143), 2018.

[21] T. Yan, M. Zhang, Y. Shi, and Y. Li, "Dichloromethane-Extract of Propolis (DEP) and DEP/PLA Electrospun Fiber Membranes," Fibres \& Textiles in Eastern Europe, Vol. 26(6), pp. 57-62, 2018.

[22] S. Sanpa, M. Popova, V. Bankova, T. Tunkasiri, S. Eitssayeam, and P. Chantawannakul, "Antibacterial Compounds from Propolis of Tetragonula laeviceps and Tetrigona melanoleuca (Hymenoptera: Apidae) from Thailand," Plos One, Vol. 10(5), 2015.

[23] F. M. Sariguzel, E. Berk, A. N. Koc, H. Sav, and G. Demir, "Antifungal Activity of Propolis Against Yeasts Isolated From Blood Culture: In Vitro Evaluation," Journal of Clinical Laboratory Analysis, Vol. 30(5), pp. 513-516, 2015.

[24] I. A. Freires, V. V. C. P. P. Queiroz, V. F. Furletti, M. Ikegaki, S. M. de Alencar, M. C. T. Duarte, et al., "Chemical Composition and Antifungal Potential of Brazilian Propolis Against Candida spp., ” Journal de Mycologie Médicale, Vol. 26(2), pp. 122-132, 2016.

[25] L. Awawdeh, A. Jamleh, and M. A. Beitawi, "The Antifungal Effect of Propolis Endodontic Irrigant with Three Other Irrigation Solutions in Presence and Absence of Smear Layer: An In Vitro Study," Iranian Endodontic Journal, Vol. 13(2), pp. 234-239, 2017.

[26] S. D. Sokeng, E. Talla, P. Sakava, M. A. F. Tagne, C. Henoumont, L. Sophie, et al., "Anti Inflammatory and Analgesic Effect of Arachic Acid Ethyl Ester Isolated from Propolis," Hindawi BioMed Research International, Vol. 2020: 8797284, 2020.

[27] Y. Yuan, S. Zheng, L. Zeng, Z. Deng, B. Zhang, and H. Li, "The Phenolic Compounds, Metabolites, and Antioxidant Activity of Propolis Extracted by Ultrasound-Assisted Method," Journal of Food Science, Vol. 84(12), pp. 3850-3865, 2019.

[28] Md. Z. N. Basyirah, A. Azemin, M. M. M. Rodi, and K. S. Mohd, "Chemical Composition and Antioxidant Activity of Stingless Bee Propolis from Different Extraction Methods," International Journal of Engineering and Technology, vol. 7(4.43), pp. 90-95, 2018.

[29] Y. M. Boufadi, P. V. Antwerpen, I. C. Alard, J. Nève, N. Djennas, A. Riazi, et al. "Antioxidant Effects and Bioavailability Evaluation of Propolis Extract and Its Content of Pure Polyphenols," Journal of Food Biochemistry, Vol. 7(4.43), pp. 90-95, 2017.

[30] B. A. Rocha, P. Beuno, M. M. D. O. L. L. Vaz, A. P. Nascimento, "Evaluation of a Propolis Water Extract
Using a Reliable RP-HPLC Methodology and In Vitro and In Vivo Efficacy and Safety Characterisation," Evidence-based Complementary and Alternative Medicine, Vol. 2013(4):670451, 2013.

[31] S. D. Marco, M. Piccioni, R. Pagiotti, and D. Pietrella, "Antibiofilm and Antioxidant Activity of Propolis and Bud Poplar Resins versus Pseudomonas aeruginosa," Evidence-Based Complementary and Alternative Medicine, Vol. 2017(ID 5163575), 2017.

[32] M. K. Choudhari, R. Haghniaz, J. M. Rajwade, and K. M. Paknikar, "Anticancer Activity of Indian Stingless Bee Propolis: An In Vitro Study," Pubmed Evidencebased Complementary and Alternative Medicine, Vol. 2013(1):928280, 2013.

[33] D. M. Colvin, "A Review on Comparison of the Extraction Methods Used in Licorice Root: Their Principle, Strength and Limitation," Medicinal \& Aromatic Plants, Vol. 7(6), pp. 1-4, 2018.

[34] N. N. Azwanida, "A Review on The Extraction Methods Use in Medicinal Plants, Principle, Strength And Limitation," Med Aromat Plants, Vol. 4(196), 2015.

[35] J. D. Phillipson, "Phytochemistry and Medicinal Plants," Phytochemistry, Vol. 56(3), pp. 237-243, 2001.

[36] Q. Zhang, L. Lin, and W. Ye, "Techniques for Extraction and Isolation Of Natural Products: A Comprehensive Review," BMC Chinese Medicine, Vol. 13:20, 2018.

[37] N. Raaman, Phytochemical techniques, 1st ed, New Delhi: New India Publishing Agency, 2006, pp. 19-25.

[38] S. M. Dhivya, and K. Kalaichelvi, "Phytochemical Studies and Gas Chromatography-Mass Spectrometry Analysis of Sarcostemma brevistigma, Wight and Arn," Asian Journal Pharm Clinical Research, Vol. 10(3), pp. 462-466, 2017.

[39] P. B. K. Khoza, M. J. M. Moloto, and L. M. Sikhwivhilu, "The Effect of Solvents, Acetone, Water, and Ethanol, on the Morphological and Optical Properties of $\mathrm{ZnO}$ Nanoparticles Prepared by Microwave Phindile B," Hindawi Journal of Nanotechnology, Vol. 2012, 195106, 2012.

[40] C. Sun, Z. Wu, Z. Wang, and H. Zhang, "Effect of Ethanol/Water Solvents on Phenolic Profiles and Antioxidant Properties of Beijing Propolis Extracts," Hindawi Publishing Corporation Evidence-Based Complementary and Alternative Medicine, Vol. 2015, ID 595393, 2015.

[41] D. Devequi-Nunes, B. A. S. Machado, G. D. A. Barreto, J. R. Silva, D. R. D. Silva, J. L. C. D. Rocha, et al. "Chemical Characterization and Biological Activity of Six Different Extracts of Propolis Through Conventional Methods and Supercritical Extraction," PLoS One, Vol. 13(12): e0207676, 2018. 
[42] L. F. Ballesteros, J. A. Teixeira, and S. I. Mussatto, "Selection of the Solvent and Extraction Conditions for Maximum Recovery of Antioxidant Phenolic Compounds from Coffee Silverskin," Springer Food Bioprocess Technol, Vol. 7, pp. 1322-1332, 2013.

[43] K. Waszkowiak, and A. GliszczyńskaŚwigło, "Binary Ethanol-Water Solvents Affect Phenolic Profile and Antioxidant Capacity of Flaxseed Extracts," European Food Research and Technology, Vol. 242(5), 2015.

[44] B. Lawal, O. K. Shittu, A. N. Abubakar, I. A. Olalekan, A. M. Jimoh, A. K. Abdulazeez, "Drug Leads Agents from Methanol Extract of Nigerian Bee (Apis mellifera) Propolis," Journal of Intercultural Ethnopharmacology, Vol. 5(1), pp. 43-8, 2016.

[45] K. Utispan, B. Chitkul, and S. Koontongkaew, "Cytotoxic Activity of Propolis Extracts from the Stingless Bee Trigona sirindhornae Against Primary and Metastatic Head and Neck Cancer Cell Lines," Asian Pacific Journal of Cancer Prevention, Vol. 18(4), pp. 1051-1055, 2017.

[46] I. H. C. Meneses, G. A. M. Sampaio, F. G. Carvalho, E. A. Münchow, M. M. Pithon, P. M. Alves, et al., "In Vivo Biocompatibility, Mechanical, and Antibacterial Properties of Cements Modified with Propolis in Different Concentrations," European Journal of Dentistry, Vol. 14(1), pp. 77-84, 2020.

[47] R. M. Abdallah, A. M. Abdelghany, N. S. Aref, "Does Modification of Amalgomer with Propolis Alter Its Physicomechanical Properties? An In Vitro Study," Hindawi International Journal of Biomaterials, Vol. 2020, 2020.

[48] J. H. Junior, L. A. Valadas, S. Fonseca, P. Lobo, L. H. Calixto, A. G. Lima, et al., " Clinical and Microbiological Evaluation of Brazilian Red Propolis Containing-Dentifrice in Orthodontic Patients: A Randomized Clinical Trial," Hindawi Evidence-Based Complementary and Alternative Medicine, Vol. 2020, 2020 .

[49] M. Dehghani, M. Abtahi, N. Hasanzadeh, Z. Farahzad, M. Noori, and M. Noori, "Effect of Propolis Mouthwash on Plaque and Gingival Indices Over Fixed Orthodontic Patients," Journal of Clinical and Experimental Dentistry, Vol. 11(3), pp. 244-9, 2019.

[50] N. Samet, C. Laurent, S. M. Susarla, N. SametRubinsteen, "The Effect of Bee Propolis on Recurrent Aphthous Stomatitis: A Pilot Study," The journal Clinical Oral Investigations, Vol. 11(2), pp. 143-147, 2007.

[51] A. Jain, D. Deepti, S. Sonkusre, A. Singh, T. Taunk, P. Sood, "Propolis: A Boon of Nature- An Overview," Scholars Journal of Applied Medical Sciences, Vol. 3(2E), pp. 873-877, 2015.

[52] Z. Khurshid, M. Naseem, M. S. Zafar, S. Najeeb, and S. Zohaib, (). Propolis: A Natural Biomaterial for
Dental and Oral Health Care," Journal of Dental Research, Dental Clinics, Dental Prospects, Vol. 11(4), pp. 265-274, 2017.

[53] S. Malhotra, and V. K. Gupta, "Use of Propolis in Pediatric Dentistry," Journal of Dental and Allied Sciences, Vol. 3, pp. 93-98, 2014.

[54] H. M. N. Iqbal, and T. Keshavarz, "The challenge of biocompatibility evaluation of biocomposites," in Biomedical Composites, 2nd ed, L. Ambrosio, ed. Woodhead Publishing, 2017, pp. 303-334.

[55] J. C. Wataha, "Principles of Biocompatibility for Dental Practitioners," The Journal of Prosthetic Dentistry, Vol. 86(2), pp. 203-209, 2001.

[56] L. C. Keong, and A. S. H. Halim, "In Vitro Models in Biocompatibility Assessment for Biomedical Grade Chitosan Derivatives in Wound Management," International Journal of Molecular Sciences, Vol. 10(3), pp.1300-1313, 2009.

[57] A. Al-Shaher, J. Wallace, S. Agarwal, W. Bretz, D. Baugh, "Effect of Propolis on Human Fibroblasts from the Pulp and Periodontal Ligament," Journal of Endodontics, Vol. 30(5), pp. 359-361, 2004.

[58] B. Shi, Y. Zhao, and X. Yuan, "Effects of MTA and Brazilian propolis on the biological properties of dental pulp cells," Original Research Endodontic Therapy, Vol. 33:117, 2019.

[59] L. Grenho, J. Barros, C. Ferreira, V. R. Santos, F. J. Monteiro, M. P. Ferraz, "In Vitro Antimicrobial Activity and Biocompatibility of Propolis Containing Nanohydroxyapatite," Biomed Mater, Vol. 10(2):025004, 2015

[60] I. A. A. Raheem, A. A. Razek, A. A. Elgendy, D. A. Labah, N. M. Saleh, "Egyptian Propolis-Loaded Nanoparticles as a Root Canal Nanosealer: Sealing Ability and in vivo Biocompatibility," International Journal of Nanomedicine, Vol. 15, pp. 5265-5277, 2020.

[61] M. C. Almeida, L.C. L. Ferreira, G. N. Venâncio, R. F. S. Souza, E. S. Lima, N. C. O. Conde, et al., "Biocompatibility of Propolis in Subcutaneous Tissue of Rats: A Possible Biomaterial for Cavity Cleansing," Revista Odonto Ciencia, Vol. 32(2), 2017.

[62] A. Eskandarinia, A. Kefayat, M. Agheb, M. Rafienia, M. A. Baghbadorani, S. Navid, et al., "A novel Bilayer Wound Dressing Composed of A Dense Polyurethane/Propolis Membrane and a Biodegradable Polycaprolactone/Gelatin Nanofibrous Scaffold," Scientific Reports, Vol. 10(1), 2020.

[63] K. Kripal, S. M. Manjunath, S. M. Shivanagendra, D. S. M. Kumar, S. S. M. Soma, R. B. Sushma, et al., "Health from the Hive: 5\% Propolis Mouth Wash as an Adjunct in the Treatment of Chronic Generalized Gingivitis-A Randomized Controlled Clinical Trial," Dentistry, Vol. 9(1):1000533, 2019. 
[64] S. O. Majekodunmi, "Review of extraction of medicinal plants for pharmaceutical research," Merit research journal of medicine and medical sciences, Vol. 3(11), pp. 521-527, 2015.

[65] B. Kaufmann, and P.Christen, "Recent extraction techniques for natural products: Microwave-assisted extraction and pressurized solvent extraction," Phytochemical analysis, Vol. 13, pp.105-113, 2002.

[66] J. P. Maran, S. Manikandan, C.V. Nivetha, R. Dinesh, "Ultrasound assisted extraction of bioactive compounds from Nephelium lappaceum L. fruit peel using central composite face centered response surface design," Arabian journal of chemistry, Vol. 10, pp. 1145-1157, 2017.

[67] G. Thrivikraman, G. Madras, and B. Basu, "In Vitro/In Vivo Assessment and Mechanisms of Toxicity of Bioceramic Materials and Its Wear Particulates," The Royal Society of Chemistry, Vol. 4, pp. 12763-1278, 2014.

[68] A. M. Gómez-Caravaca, M. Gómez-Romero, D. Arráez-Román, A. Segura-Carretero, and A. Fernández-Gutiérrez, "Advances in The Analysis of Phenolic Compounds in Products Derived from Bees," Journal of Pharmaceutical and Biomedical Analysis, Vol. 41, pp. 1220-1234, 2006. 